\title{
ROZDÍLY VÝŠEK V SYSTÉMU BPV A VÝŠEK ZALOŽENÝCH NA MODELU EGM96
}

\author{
DIFFERENCES BETWEEN HEIGHTS IN THE BPV SYSTEM AND \\ HEIGHTS BASED ON THE EGM96 MODEL
}

\author{
Zuzana Vaňková*,1 \\ "zuzana.vankova@fssv.cvut.cz \\ 'ČVUT v Praze, Fakulta stavební, Katedra geomatiky, Thákurova 7, 16629 Praha 6
}

\begin{abstract}
Abstrakt
Tato práce se zabývá určením rozdílů mezi výškami v systému Bpv a výškami založenými na geopotenciálním modelu EGM96. Výškový rozdíl je vypočten jako rozdíl odlehlosti geoidu a výškové anomálie kvazigeoidu, kde obě veličiny jsou vztaženy ke stejnému referenčnímu elipsoidu. Část práce se věnuje určení odlehlosti geoidu ze sady Stokesových koeficientů pro model gravitačního pole EGM96. Dále jsou pro potřeby této práce použity modely kvazigeoidu CR-2005 a QGZÚ-2013, které jsou popsány hodnotami výškové anomálie v pravidelné síti. Dalším použitým zdrojem dat je soubor bodů výběrové údržby ZÚ. Tyto body mají měřenou elipsoidickou výšku metodou GNSS a také nivelovanou výšku v Bpv. Prostřednictvím těchto hodnot je na nich možno výpočtem určit hodnotu výškové anomálie.
\end{abstract}

\section{Klíčová slova}

EGM96, normální Moloděnského výšky, odlehlost geoidu, Stokesovy ortometrické výšky, výšková anomálie

\begin{abstract}
This work deals with determining the differences between heights in the Bpv system and heights based on the geopotential model EGM96. The height difference is calculated as the difference between the geoid undulation and the height anomaly of the quasigeoid, where both quantities are related to the same reference ellipsoid. Part of the work is devoted to determining the undulation of the geoid from a set of Stokes coefficients for the gravitaty field model EGM96. Furthermore, the quasigeoid models CR-2005 and QGZÚ-2013 are used for the needs of this work, which are described by the values of the height anomaly in the regular grid. Another source of data used is a set of selective maintenance points.
\end{abstract}

Key words

EGM96, normal Molodensky height, geoidal undulation, Stokes orthometric heights, height anomalies

\section{1 ÚVOD}

Tato práce se zabývá výškovým systémem baltským po vyrovnání (dále jen Bpv) a geopotenciálním modelem EGM96. Jejím cílem bylo určit pro území ČR rozdíly výšek v systému Bpv a výšek vztažených ke geopotenciálnímu modelu EGM96, a to na základě dat dvou modelů kvazigeoidu (CR-2005 a QGZÚ-2013) a souboru Stokesových koeficientů, jimiž je popsán model EGM96.

Motivací k realizaci této práce jsou potřeby civilního letectví, kde jsou mezinárodně určovány výšky založené na modelu EGM96. V závazném výškovém systému ČR se však určují výšky v systému Bpv, z čehož vyplývá potřeba převodu výšek pro území ČR.

Uvedený rozdíl výšek není konstantní, ale mění se v závislosti na zeměpisné poloze. Proto bylo uvažováno takové řešení, pomocí kterého by bylo možno určit výškové rozdíly pro body v pravidelné síti na řešeném území. A to $\mathrm{s}$ dostatečnou hustotou tak, aby výškový rozdíl pro konkrétní souřadnice mohl být snadno dopočten interpolací z okolních hodnot $\mathrm{s}$ dostačující přesností. Takovéto řešení bylo vhodné jak z hlediska využití výsledků, tak z hlediska řešení výpočtu jako takového. Výpočet bod po bodu by byl sice teoreticky snadný, ovšem časově velice náročný pro uvažované velké množství výpočetních bodů. Tedy cílem bylo upravit výpočet tak, aby byly výsledky hromadně určeny pro celou sít' výpočetních bodů. 


\section{LITERÁRNÍ PŘEHLED/POPIS SOUČASNÉHO STAVU}

Výškové rozdíly na základě dat modelů kvazigeoidu CR-2005 a QGZÚ-2013 a modelu EGM96 dosud nebyly určeny globálně pro území ČR. Obdobné problematice se věnuje práce [1], ovšem je řešena pro starší model kvazigeoidu (CR2000). Metodice efektivního výpočtu sféricko-harmonického rozvoje, který je v práci obsažen, se věnuje [2]. Obecně se tématu teorie výšek věnuje např́klad [3].

\section{METODIKA}

Primárně bude následující kapitola věnována obecnému nastínění teoretického kontextu výpočtu, čímž bude v podstatě shrnut obecný princip řešení. Konkrétní řešení bude shrnuto pouze okrajově (detailně je způsob výpočtu řešen např́klad v [1]).

\section{Řešení obecně}

Výšky v systému Bpv odpovídají Moloděnského řešení tvaru Země, které vychází ze vztahu:

$$
h_{\mathrm{el}}=H_{\mathrm{Q}}+\zeta,
$$

kde $h_{\mathrm{el}}$ je elipsoidická výška, $H_{\mathrm{Q}}$ je normální Moloděnkého výška a $\zeta$ je výšková anomálie. Ani jedna z uvedených výšek nemá fyzikální význam. Elipsoidická výška je vzdálenost mezi bodem na povrchu Země a jeho průmětem po normále na zvolený elipsoid. Význam Moloděnského výšky je znázorněn na Obr.1 jako vzdálenost měřená po normále mezi bodem $\mathrm{Q}$ a elipsoidem. Bod $\mathrm{Q}$ byl nalezen na normále $\mathrm{k}$ elipsoidu procházející bodem $\mathrm{P}$ na zemském povrchu jako bod, $\mathrm{v}$ němž je normální tíhový potenciál roven tíhovému potenciálu v bodě P. Množina takových bodů tvoří plochu zvanou teluroid. Vzdálenost mezi zemským povrchem a teluroidem je označována jako výšková anomálie. Pokud by (pro jistou analogii s geoidem) byly výškové anomálie vyneseny nad elipsoidem, byla by získána plocha zvaná kvazigeoid.

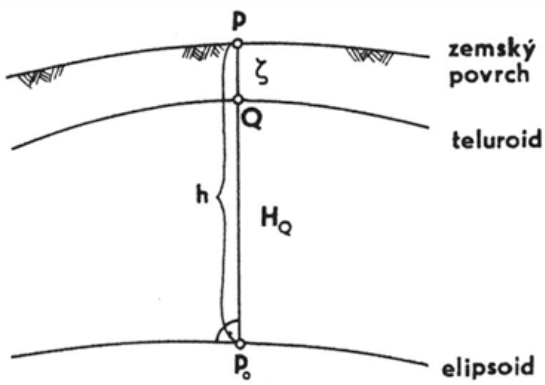

Obr. 1 Moloděnského výška $H_{\mathrm{Q}}$, elipsoidická výška $h$, výšková anomálie $\zeta$ a teluroid [3].

Na základě Stokesovy teorie, jíž odpovídají ortometrické výšky vztažené k modelu EGM96, lze zapsat obdobný vztah jako (1):

$$
h_{e l}=H+N,
$$

kde $h_{\text {el }}$ značí opět elipsoidickou výšku, $H$ je ortometrická (geoidická) výška a $N$ je odlehlost geoidu od elipsoidu. Ortometrické výšky udávají vzdálenost bodu na zemském povrchu od jeho průmětu podél tížnice na geoid a mají fyzikální význam. Mohly by vyvstat pochybnosti o rovnosti ve vztahu (2) z důvodu, že elipsoidické výšky se měří po normále a ortometrické výšky podél tížnice. Tímto způsobený rozdíl je však velmi malý, tudíž pro potřeby této práce zanedbatelný. Kombinací vztahů (1) a (2) je po úpravě získán vztah pro rozdíl výšek:

$$
H_{\mathrm{Q}}-H=N-\zeta \text {. }
$$

Uvedený vztah (3) umožňuje určit hledaný rozdíl výšek jako rozdíl odlehlosti geoidu a výškové anomálie, což je vzhledem $\mathrm{k}$ podkladovým datům vhodné řešení. Výše uvedené skutečnosti jsou pro lepší představu o vztahu výšek zobrazeny na Obr.2, z něhož je např́ílad patrné, že hledaný rozdíl výšek (označen jako $\Delta h$ ) je v podstatě vzdálenost mezi bodem na geoidu a odpovídajícím bodem na kvazigeoidu [3], [4], [5]. 


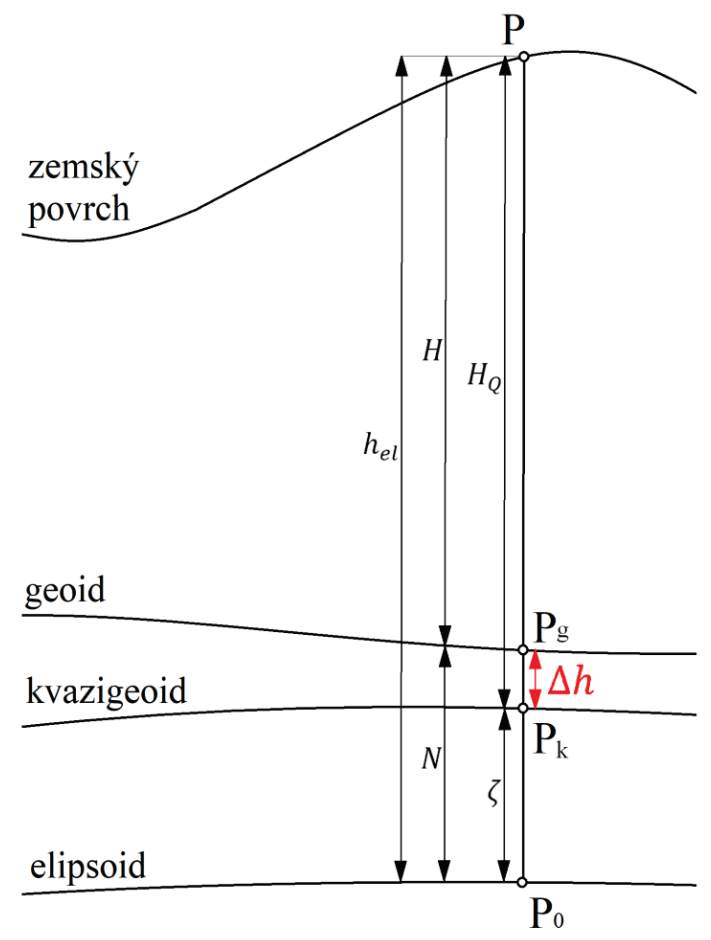

Obr. 2 Vztahy výšek.

\section{Použitá data}

Pro realizaci výpočtu je nezbytná znalost použitých dat. Část vstupních dat tvoří geopotenciální model EGM96. Model je popsán sadou plně normovaných Stokesových koeficientů, což jsou harmonické geopotenciální koeficienty v rozvoji tíhového potenciálu v řadu kulových funkcí, a to do stupně (resp. řádu) 360 .

Modely kvazigeoidu (CR-2005 a QGZÚ-2013) jsou popsány hodnotami výškové anomálie pro body v pravidelné síti na území ČR s danými geodetickými souřadnicemi. Jde o hodnoty vztažené k elipsoidu GRS80.

\section{Realizace výpočtu}

Výpočet byl realizován v programu Matlab. Podle vztahu (3) je rozdíl výšek vypočten jako rozdíl odlehlosti geoidu a výškové anomálie. Výšková anomálie je v rámci podkladových dat známa. Je tedy nutno věnovat se určení odlehlosti geoidu.

V rámci výpočtu bylo řešeno několik dílčích částí, kde jádro tvoří výpočet normovaných Legendreových přidružených funkcí. Pomocí nich je poté realizován výpočet průvodiče geoidu, který je odvozen ze vztahu pro tíhový potenciál. Celkový výpočet pak řeší určení odlehlosti. Komplikovanost tohoto výpočtu vychází ze skutečnosti, že dané vstupní sourăadnice jsou geodetické, ale jako vstup do všech dílčích výpočtu jsou potřebné souřadnice geocentrické. Výpočet geocentrických souřadnic však závisí na hodnotě průvodiče, kterou bez známých geocentrických souřadnic nelze přesně určit. Finální výpočet $\mathrm{z}$ tohoto dủvodu obsahuje vnitřní a vnější iteraci. Vnitřní iterace řeší hodnotu odlehlosti a zpětné určení geodetických souřadnic pomocí aktuální hodnoty souřadnic geocentrických a průvodiče. Vnější iterace pak řeší opravu geocentrických souřadnic na základě výsledku vnitřní iterace a výpočet nové hodnoty průvodiče. Nutnost tohoto řešení zcela zjevně navyšuje časovou náročnost výpočtu.

Vzhledem $\mathrm{k}$ množství dat (body v síti po $1^{`}$ zeměpisné šírky a po $1,5^{`}$ zeměpisné délky) je výpočet bod po bodu nevhodný a je třeba provést úpravu takovou, aby byl výpočet řešen naráz pro celou sít bodů. Aby to bylo možné, je potřeba upravit dílčí výpočty. Postup úpravy výpočtu průvodiče je řešen např́ílad v [2]. V podstatě jde o nahrazení sumace maticovým násobením, což významně urychlí výpočet a umožní vypočítat hodnoty naráz, pokud se jedná o body v pravidelné síti. Za zmínku v tomto kontextu stojí nutnost zavedení metody 
řádkových průměrů podle [1], aby byly vyřešeny neodpovídající rozměry matic $\mathrm{v}$ jejich součinu podle [2] (problém s rozměry matic totiž při výpočtu pro více zeměpisných délek nezbytně nastane). Tato metoda spočívá v průměrování řádků matice, v níž rádky odpovídají zeměpisným šířkám a sloupce zeměpisným délkám (tedy hodnoty v rámci jednoho řádku odpovídají neměnné zeměpisné šířce a postupně po sloupcích všem zeměpisným délkám). Uvedeným řádkovým průměrem je pro jednu zeměpisnou šířku získána odpovídající průměrná hodnota podle více zeměpisných délek. Aby byl výpočet realizován s dostatečnou přesností, je nutné hodnoty zeměpisné délky rozdělit na několik pásů (intervalů) a výpočet, tedy i řádkové průměry, realizovat pouze $\mathrm{v}$ rámci pásu (na základě testování výběrové množiny bodů bylo pro tuto práci stanoveno jako dostatečně přesné použití 10 pásů zeměpisné šířky pro ČR).

Dále byl upraven i výpočet normovaných přidružených Legendreových funkcí, pro nějž byly použity vztahy uvedené např́iklad v [6]. Protože již nebyla potřeba celá matice těchto funkcí, byl výpočet upraven tak, aby byla vždy určena potřebná konkrétní část této matice.

Závěrem pak byl vypočten hromadně pro všechna data rozdíl odlehlosti geoidu a výškové anomálie (tedy rozdíl výšky v systému Bpv a rozdíl výšky vztažené ke geopotenciálnímu modelu EGM96).

\section{VÝSLEDKY}

Výsledkem práce jsou textové soubory s určenými hodnotami rozdílu výšek v gridu na území celé ČR s body po $1^{`}$ zeměpisné šiřrky a po $1,5^{`}$ zeměpisné délky. Výsledné rozdíly výšek získané na základě dat modelu QGZÚ-2013 se pohybovaly mezi $-4 \mathrm{~cm}$ a $121 \mathrm{~cm}$. Výsledky získané na základě dat modelu CR-2005 byly $\mathrm{v}$ intervalu od $0 \mathrm{~cm}$ do $122 \mathrm{~cm}$. Tyto výstupy byly dále zpracovány v softwaru ArcGIS Pro. Pomocí interpolace metodou inverzních vzdáleností byly vyhotoveny rastry výškových rozdílů jako podklad pro posouzení výsledků.

Pro prezentaci výsledků byl vyhotoven grafický výstup zobrazující výškové rozdíly pomocí barevné hypsometrie a vrstevnic (viz Obr.3). Jde o výsledky vyhotovené na základě dat modelu QGZÚ-2013, výsledek na základě dat modelu CR-2005 byl v tomto měřítku obdobný.

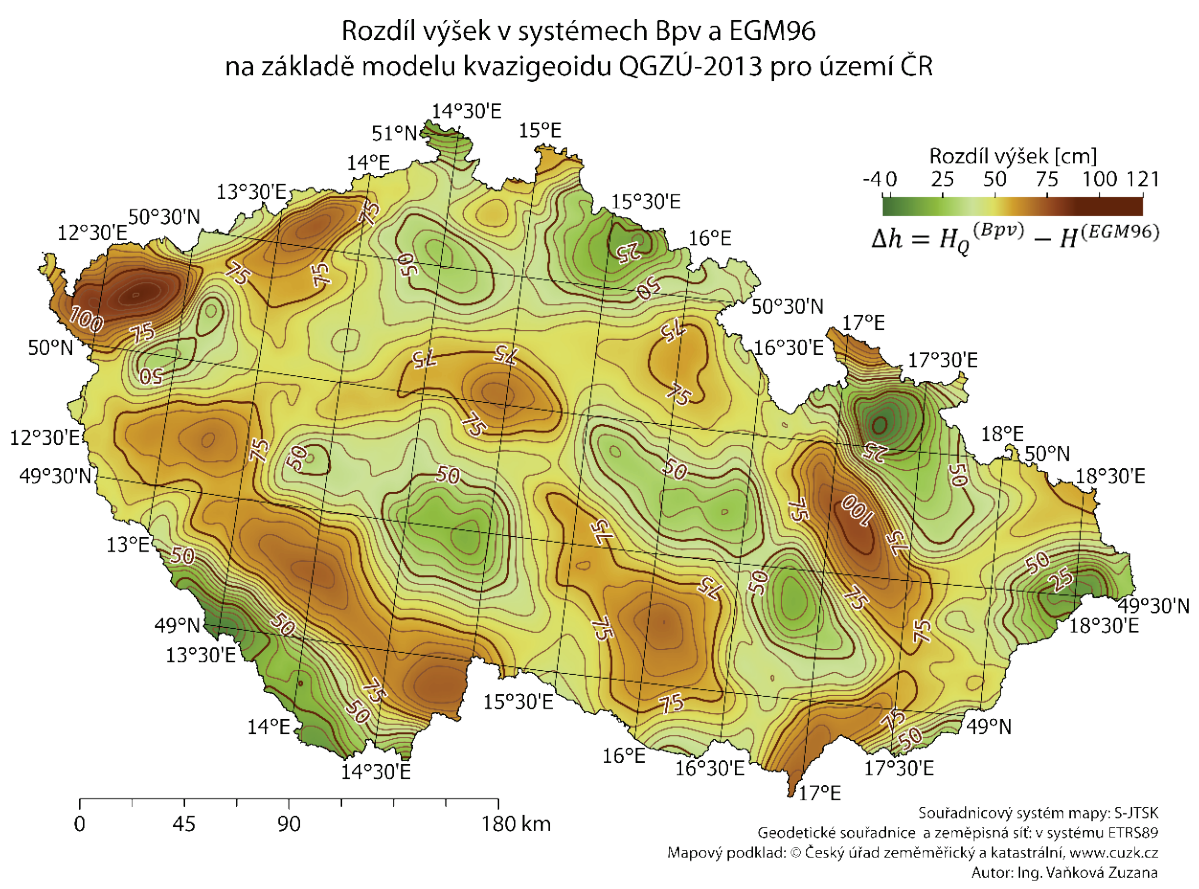

Obr. 3 Vizualizace rozdílů výšek.

Srovnání výsledků podle obou modelů je vizualizováno v Obr. 4 jako diference vytvořených rastrů výškových rozdílů, tedy $\mathrm{v}$ podstatě jde o rozdíl hodnot výškové anomálie. Výsledky se lišily v extrémních př́ipadech o $14 \mathrm{~cm}$. 


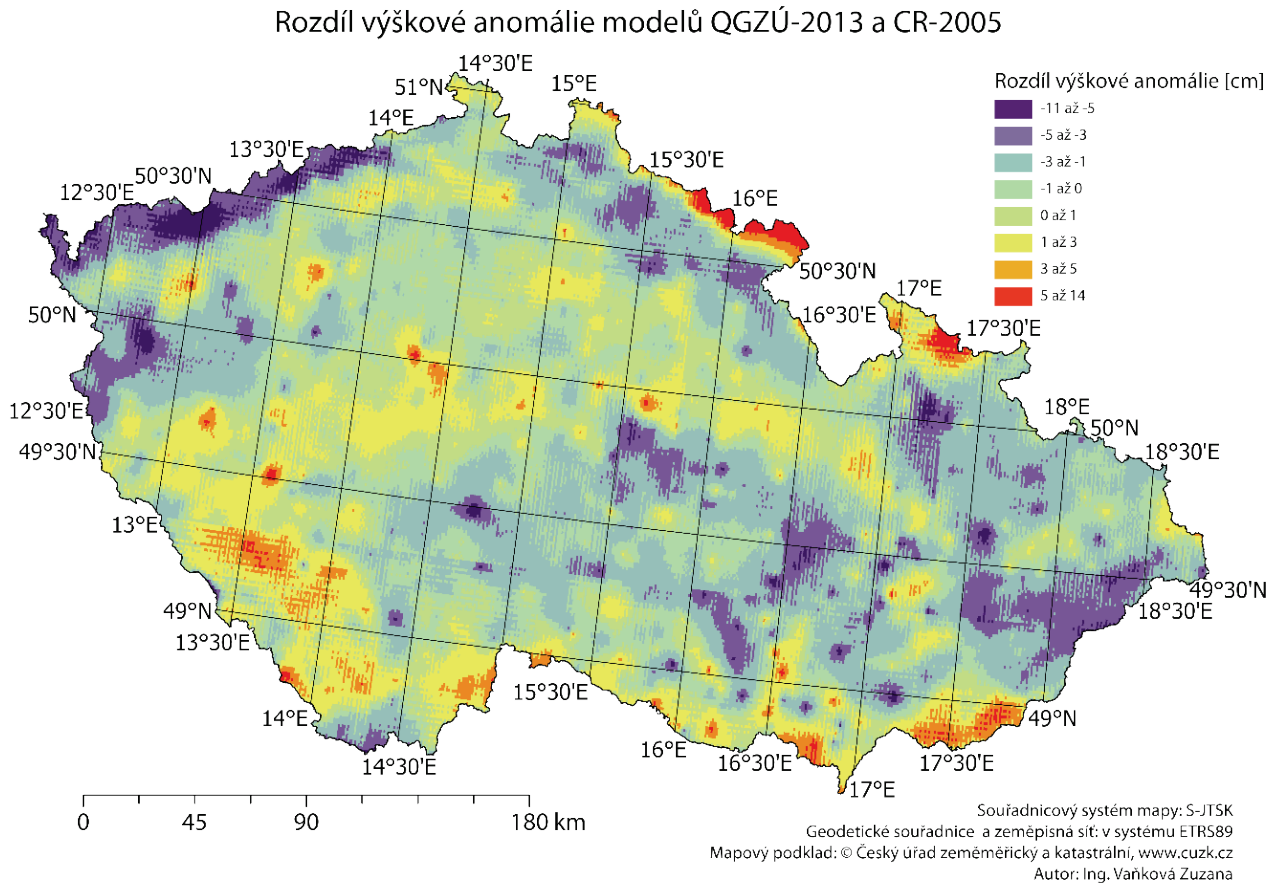

Obr. 4 Srovnání modelů CR-2005 a QGZÚ-2013.

\section{DISKUZE}

Pro posouzení výsledků byla využita data GNSS-nivelace na bodech výběrové údržby ZÚ, na nichž byla známa měřená výška v systému Bpv a také výška elipsoidická. Jednoduchým rozdílem byla určena hodnota výškové anomálie na těchto bodech a poté na nich byla vypočtena hodnota výškového rozdílu. Takto získané výškové rozdíly byly považovány za výsledky s vyšší přesností než výsledky řešené na základě dat modelů kvazigeoidu, protože byly založeny na přímo měřených hodnotách. Jejich využití pro komplexní výstup ale nebylo možné, z důvodu malého množství bodů a jejich nepravidelného rozmístění pro oblast ČR.

Výsledné hodnoty byly porovnány pomocí vypočtení diference výškových rozdílů. A to mezi výsledky získanými pomocí dat GNSS-nivelace a výsledky vypočtenými na základě dat modelů kvazigeoidu, pro něž byly příslušné výškové rozdíly odečteny $\mathrm{z}$ vyhotovených rastrů $\mathrm{v}$ požadovaných bodech. Byly určeny statistické hodnoty popisující rozložení diferencí výškových rozdílů. Pro porovnání na základě modelu CR-2005 byla směrodatná odchylka $2,12 \mathrm{~cm}$, aritmetický průměr $0,81 \mathrm{~cm}$ a střední hodnota $0,80 \mathrm{~cm}$. Diference výškových rozdílů na základě modelu QGZÚ-2013 měly směrodatnou odchylku 2,37 cm, aritmetický průměr $0,30 \mathrm{~cm}$ a střední hodnotu $0,40 \mathrm{~cm}$. Směrodatná odchylka tedy vycházela spíše ve prospěch výsledků na základě modelu CR-2005, ovšem střední hodnota i hodnota aritmetického průměru hovořila jednoznačně ve prospěch modelu QGZÚ-2013.

Nejvyšší diference ve výsledcích byly pozorovány $\mathrm{v}$ pohraničních oblastech a to pro oba modely kvazigeoidu, což je jistě ovlivněno nižší přesností modelů na okrajích ČR a v horských oblastech. (,Úplná střední chyba výškové anomálie zeta činí na území ČR $1 \mathrm{~cm}, v$ horském terénu a v príhraničních oblastech (do $10 \mathrm{~km}$ od státnich hranic) může dosahovat hodnot vyššich, nejvýše však $3 \mathrm{~cm}$. " [8])

Dále je nutné v uvedeném posouzení přihlédnout k té skutečnosti, že vznik modelu CR-2005 je vázán na body GNSS-nivelace: „...model kvazigeoidu CR-2005, který byl odvozen navázáním modelu CR-2000 na sit’ 1024 bodů výběrové údržby, jejichž výška byla určena nivelací. " [7] Oproti tomu model QGZÚ-2013 je vázán na jiná data, která s daty GNSS-nivelace nesouvisejí: „,Model kvazigeoidu byl získán kombinovaným regionálním rešením lineárni gravimetrické okrajové úlohy pro poruchový gravitačni potenciál zemského tělesa, a to za významného prispéni revidovaného kompletního souboru podrobných bodů gravimetrických mapování ČR zaměrených při geofyzikálním průzkumu mezi lety 1950 až 2010 a dalšich dat. " [8] Tedy lze předpokládat, že 
srovnání výsledků získaných na základě dat GNSS-nivelace s výsledky na základě modelu CR-2005 tím bude do značné míry ovlivněno.

Model QGZÚ-2013 je dle [8] pravidelně aktualizován a obsahuje podrobnější data než model CR-2005. Podrobnost dat není vždy výhodou, např́iklad pro účely globálního výpočtu jsou data až př́liš podrobná. Proto ani v rámci této práce nebyla využita všechna data (byla redukována na stejnou podrobnost, jakou má model CR-2005). Tento model by se rozhodně více hodil pro výpočet rozdílů výšek pro menší oblasti, nikoli pro celou ČR, kde nemůže být využit celkový potenciál modelu vycházející z podrobnosti dat.

S přihlédnutím k výše uvedeným skutečnostem, byl nakonec vybrán model QGZÚ-2013 jako podklad pro výškové rozdíly, které budou dále prezentovány. Nelze ovšem říci, že by byl některý z modelů výrazně horší nebo lepší.

\section{ZÁVĚR}

Stanovený cíl práce, tedy určit rozdíly výšek v systému Bpv a výšek vztažených k modelu EGM96 pro území ČR na základě různých vstupních dat, byl splněn. Výškové rozdíly byly také porovnány mezi sebou a byl vybrán model QGZÚ-2013 jako podklad pro výsledky, které budou př́padně dále řešeny a prezentovány. Výstupy práce byly zpracovány formou textového souboru obsahujícího body $\mathrm{v}$ pravidelné síti s odpovídajícími hodnotami rozdílů výšek, odlehlosti geoidu od elipsoidu a výškové anomálie. Z tohoto souboru je možné pomocí interpolace vypočítat hodnoty pro body mimo sít'. Pro získání mnohem přesnějších hodnot výškových rozdílů konkrétních bodů by bylo možno na výsledky práce navázat vytvořením výpočetní aplikace s využitím obdobných metod a modelů.

$\mathrm{V}$ průběhu cesty vedoucí k naplnění stanovených cílů se vyskytlo mnoho komplikací, které bylo nutno korektně vyřešit. Za zmínku stojí například výpočet průvodiče geoidu, kde se vyskytlo potíží nejvíce, a to zejména z důvodu výpočetní rychlosti a kapacity operační paměti výpočetního zařízení. Proto musela být využita metoda řádkových průměrů (podle [1]), díky které sice počítáme hodnoty přibližné, ale s dostatečnou přesností pro cílový výsledek (pro rozdělení na 10 pásů zeměpisné délky nepřesahuje maximální odchylka $1 \mathrm{~mm}$ ). Tento krok vedl k výraznému zvýšení výpočetní rychlosti, protože velikost průvodiče může být určena naráz pro velké množství bodů pomocí maticového násobení.

Další výraznou komplikací bylo př́liš velké množství dat souborů pro model kvazigeoidu QGZÚ-2013. Data bohužel nemohla být využita všechna ze zřejmých výpočetních důvodů. Také pro realizaci výstupu by data byla př́liš podrobná, proto byl problém vyřešen redukcí vstupních dat na méně podrobnou sít' (ze sítě se zeměpisnou šiřkou i délkou po 3 " byla data redukována na sít’ po $1^{‘}$ zeměpisné šířky a po $1,5^{`}$ zeměpisné délky).

\section{Použité zdroje}

[1] HOLEŠOVSKÝ, J. Vztah výšek v systémech Bpv a EGM96 na území ČR. 2007. Diplomová práce. ČVUT, Fakulta stavební.

[2] Sphärisch harmonische Synthese - Programmierung in Matlab. Podklad ke kurzu Höhe, Schwere, Geoid na TU München, no. 10-12, červen 2006. Bez uvedení autora. 6 stran.

[3] ANTONÍN, Zeman. Fyzikální geodézie 10: teorie výšek a výškové systémy : doplňkové skriptum. Praha: Vydavatelství ČVUT, 2003. ISBN 80-01-02733-3.

[4] ANTONÍN, Zeman. Fyzikální geodézie 10. Praha: České vysoké učení technické, 1998. ISBN 80-0101849-0.

[5] MERVART, Leoš a Miloš CIMBÁLNÍK. Vyšší geodézie 2. Praha: ČVUT, 1997. ISBN 80-01-01628-5.

[6] HOLEŠOVSKÝ, J. Výpočet přidružených Legendreových funkcí [online]. [cit. 2021-5-6]. Dostupné z: ftp://athena.fsv.cvut.cz/VG/VYG2/web_data/SHS/Legendreovy_funkce.pdf

[7] KOSTELECKÝ, Jan, Jakub KOSTELECKÝ a Ivan PEŠEK. Metodika převodu mezi ETRF2000 a SJTSK varianta 2. ČÚZK [online]. Praha: ČÚZK, c 2021 [cit. 2021-5-5]. Dostupné z: https://www.cuzk.cz/Zememerictvi/Geodeticke-zaklady-na-uzemi-CR/GNSS/Nova-realizacesystemu-ETRS89-v-CR/Metodika-prevodu-ETRF2000-vs-S-JTSK-var2(101208).aspx

[8] Podrobný kvazigeoid QGZÚ-2013. ČÚZK [online]. Praha: ČÚZK, c 2021 [cit. 2021-5-5]. Dostupné z: https://geoportal.cuzk.cz/(S(svjpsfcw4dgtdxwq5xardtot))/Default.aspx?mode=TextMeta\&side=bodpo le\&metadataID=CZ-CUZK-QGZU\&head_tab=sekce-02-gp\&menu=275 